\title{
CORRESPONDENCE
}

\author{
To THE EDITOR of THE Journal of Philosophical Studies.
}

Sir,

In the number for April 1926, Father Leslie Walker writes a critique of Volume One of my History of Mediaval Philosophy, translated by Dr. Messenger. The review seems unfair in many respects, and therefore $I$ hope that you will allow me to reply briefly.

Father Walker seems to think that a history should consist of a series of monographs, without any attempt at synthesis, and hence without any groupings. Accordingly, he complains that anyone expecting to find in my book " a history of philosophy in the ordinary sense of the term will be sadly disappointed." Presumably Father Walker would wish us to return to the methods of Diogenes Laërtius, and the ancient annalists. It is safe to say that no modern historian would side with Father Walker here. The suppression of synthetic views in history would mean its decadence as a science, and I think Burnet, Boutroux, Wildelband, and Zeller, wonld agree as to this. In history, as in other subjects, every synthetic view is a construction of the mind, and is legitimate only in so far as it has a basis in objective reality.

Father Walker seems to dislike my insistence upon the " collective inheritance which the majority of mediæval thinkers sought to maintain," but immediately afterwards says himself : "No doubt there was such an inheritance." Then why should I be condemned for saying so ? I am inclined to think that in order to avoid misunderstanding it would have been preferable not to treat the period from the ninth to the twelth century as a function of the thirteenth, and I would willingly lay stress on the formative role, the eclectic value, and somewhat chaotic character of the first period. I also allow that it might have been better to expound the doctrinal patrimony of scholasticism at the end, instead of at the beginning of the study of the thirteenth century. But all these are mere details and do not affect the main point that there was such a system as scholasticism.

Again, Father Walker does not seem to like my insistence that " there were mediæval systems of philosophy distinct from theology," and accordingly criticizes my separate treatment of the philosophical and theological teaching of Roscelin and Anselm. He says that "the philosophic and the theological doctrines were in both cases closely connected." If he means by this that the theological doctrines were influenced by the philosophical ideas, I agree. In fact, I remark on page 144 that Roscelin's tritheism " is an evident application of anti-realism," and I similarly say that St. Anselm "based himself upon exaggerated realism in combating Roscelin" (p. 125). But if Father Walker means that the philosophy of these writers was intrinsically dependent on their theology, thon I must beg leave to dissent very strongly. The autonomous character of philosophy in the Middle Ages needs no defence on my part : others have proved it, and their conclusions are now generally accepted. Curiously enough, Father Walker himself admits that the distinction between philosophy and theology "was eventually brought about," but reproaches me for not giving some account of the stages of the process. I can only refer him to page 18 ("Philosophy, which was first of all confused with theology, was recognized as distinct in the twelth century"), and the whole of Chapter IV, in which I endeavour to show how " this confusion gradually passed away" (p. $\left.\mathrm{r}_{4} \mathrm{I}\right)$.

Moro serious still are the errors Father Walker falls into on the subject of universals. On the one hand he seems to think that "realist" in this connection means one who believes in the existence of any extramental reality (" St. Thomas also held that the real exists apart from the mind "), or else one who accepts the theistic position (" justice, truth, and goodness exist elsewhere than in the finite 280 


\title{
COR RESPONDEN CE
}

beings which share in them"). This betrays a complete ignorance of the essential point in the attitude of moderate realism towards the question of universals. The question was not concerned with the existence of extramental reality as such, nor with the existence of reality other than finite, but with the existence in an abstract state of justice, etc., as an entity shared in by individual things which are just. That was the thesis of the Platonists which St. Thomas so vigorously opposed. Again, Father Walker says that St. Thomas teaches that "individuals are differentiated accidentally." That is an error : in Thomism individual things do not participate in one common substance, e.g. humanity, and accordingly differ substantially from one another and not merely accidentally. Father Walker quarrels with the term "exaggerated realism," but that is a mere question of words. The expression is in current use, and even a Plantonist like Father Walker has no right to complain of it. Finally, Father Walker's remarks on the "indifferentism" of the twelth century simply run counter to historic fact. Indifferentism was certainly not a form of exaggerated realism. And Father Walker is not quite sure whether Abelard should be regarded as an opponent of Platonic realism! Comment on such an attitude is superfluous!

\author{
Yours faithfully, \\ MAURICE DE WULF \\ (Professor University Louvain and Harvard).
}

I, Rue des Chevaliers,

BRUSSELS.

To THE EDITOR OF THE Journal of Philosophical Studies.

SIR,

I regret that Professor de Wulf should deem my review of his first volume unfair, and am the more surprised that he should do so in that, when he writes "it would have been preferable not to treat the period from the ninth to the twelfth century as a function of the thirteenth," he admits the justice of my main criticism. But, whereas he thinks that this is a mere detail, in my opinion to treat three centuries of philosophy as a function of a fourth which was not their antecedent, but their consequent, is a grave defect of method in a work which claims to be a history. Needless to say, 1 object neither to syntheses nor to groupings. I object merely to the particular syntheses and groupings which Professor de Wulf has made. To have discussed the outstanding philosophy of the eleventh century before he discussed that of the ninth, for no reason that I can discover save that the latter might appear as "anti-scholasticism," is a device that shocks my sense of historical propriety. Similarly, though to treat of the philosophy of a group of authors in one chapter and of their theology in another may serve to emphasize the distinction between them, it also tends to obliterate their admitted connection, and necessitates constant reference to the index, if one would miss nothing that the author has to say about any particular medixval writer. I have no especial affection for the ancient annalists, but it does seem to me that with the chronological order the order of development cannot but be bound up, and that a historical grouping should pay attention to this, as it should also take cognizance of similarities and connections no less than of differences and opposition.

Professor de Wulf finds it strange that I should admit some of his theses, yet take exception to his having failed to susbtantiate them. "The autonomous character of philosophy in the Middle Ages," he says, " needs no defence on my part : others have proved it." Yet it would surely have been relevant in a textbook intended for students to prove it over again. I can find no such proof, not even in the chapter in which the author supposes himself to have shown "how this confusion gradually passed away" ; for the theologians of which the chapter treats are not discussed historically, but according as they may be classed as 


\section{JOURNAL OF PHILOSOPHICAL STUDIES}

'rationalistic,' 'reactionary,' or ' moderate.' Similarly, though Professor do Wulf's main thesis is that there existed a collective philosophical inheritance, distinct from the theological inheritance, and maintaining itself through the centuries in spite of vigorous opposition, we are nowhere told in what this inheritance consisted or what philosophers were in possession of it, until we reach the thirteenth century; while Anselm, whose influence in the earlier period was greater than any other, was, we are informed, an exaggerated realist.

I know quite well what Professor de Wulf means by "exaggerated realism," and by no means confuse it with what he calls " moderate realism." What I do assert, however, as against Professor de Wulf, is that neither in the writings of Anselm nor yet in that of Abelard's opponents is the theory which he calls 'exaggerated' to be found. There is no ovidence that either Anselm or William of Champeaux believed in " the existence in an absiract state of justice, etc., as an entity shared in by individual things which are just." Both held that truth and goodness existed primarily in the divine being which Anselm calls the summa natura; but there is no ground for supposing that either believed in Erigena's " primordial causes," nor yet in any other kind of realm-apart mediating betwoen creation and the divine intelligence. True, both the earlier realism and the later 'indifferentism' affirm that individuals of the same species possess something in common, and again that, if they possessed nothing beyond this common specific nature, there would be nulla penitus differentia between them. But this St. Thomas also claims when he says (De Pot., I, ix, a. I) that, if everything in particular substances pertained to their common nature, non posset esse distinctio inter substantias particulares ejusdem naturce. Thus far, therefore, St. Thomas is at one with William of Champeaux; for both affirm the reality of this common nature, yet without affirming it to exist as an entity in an abstract state; and neither accepts the bold thesis of Abelard who ascribes hujusmodi universalitatem solis vocibus (B.G.P.M., xxi, p. I6). In their theory of individuation, on the other hand, they differ; for, whereas William of Champeaux in his fust theory attributes incividuation to formal differences, and in his second theory affirms instead a discretio personalis, St. Thomas ascribes individuation primarily to the dimensive quantity to which materia prima gives rise, and secondarily et per consequens to accidentia individualia, qua materiam pradictam determinant (De Pot., loc. cit.). For St. Thomas different 'first substances,' if material, i.e., individual men, animals, things, do not differ specifically, as do pure spirits, but share in the same ' second substance' or essence, and are differentiated $(a)$ by dimensive quantity, which is an accident that of necessity emerges in all material bodies, and $(b)$ by the accidentia individualia to which it, in conjuntion with form, gives rise. Thus, while they differ in their account of individuation, St. Thomas accepts the basic principle of Anselm and William of Champeaux, since, like them, he ascribes to specific nature a unifying function which would render all things of the same nature one, unless within them in the concrete there existed also a further principle of diversity.

Abelard's precise position it would take longer to determine. Between this "Platonic realism" and his thesis that universals consist solis vocibus there is certainly a prima facie opposition. But when Abelard goes on to show how there must exist in the real order a communis causa secundum quam universale nomen impositum est (B.G.P.M., xxi, p. I9), the opposition between his doctrine and that of the realists to a certain extent disappears : so much so, in fact, that had Professor de Wulf been less fond of looking for errors, past and present, and of throwing opprobrious epithets at their supposed authors, he might perchance have discovered at least one common factor in the philosophical inheritance of the Middle Ages, and so have been able in part to substantiate his favourite thesis.

Faithfully yours,

LESLIE J. WALKER. 


\section{ORRESPON D E C E}

\section{To THE EDITOR OF THE Journal of Philosophical Studies.}

Sir,

The review of my An Introduction to Philosophy (Jonathan Capes, 1926), in your issue of July 1926 (pp. 336 and 337 ) is very unsatisfactory.

The review expands the thesis that for me "the value of philosophy lies in its finding a "meaning ' for life, not solely in satisfying a desire to know." This thesis arises from the reviewer's confusion between the intrinsic and the instrumental value of philosophy. The former is knowledge-- to think truly about human experience as a whole" (my text, p. 4.) which is an "intrinsic value" (p. I46). The latter consists in philosophy's influence on the rest of life. Who would love the ivory tower so fondly as to ignore that influence? But nowhere do I hint that a "good " influence is a precondition of the value or a test of the truth of philosophy. I explicitly reject pragmatism (Chapter II), and advocate rigid analytic and synoptic methods (Chapter I). The "serious defect" which the reviewer finds is a proposition which the book neither contains nor implies.

The review does not define the point of view of the book; mentions not a single argument which it contains; gives no reason for agreeing or disagreeing with anything save the reviewer's preconceptions about Introductions in general and those in particular which omit propositional functions and betray interest in values.

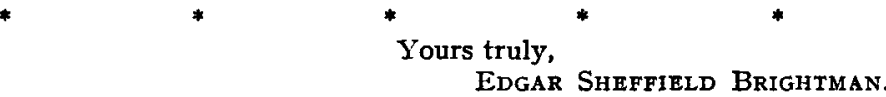

BOSTON UNIVERSITY,

Boston, Massachusetts.

TO THE EDIOR OF THE Journal of Philosophical Siudies.

DeAR Sir,

I am sorry that Professor Brightman finds my comments on his book unsatisfactory. I did not conceive it to be my business to write a " review," but to consider the merits of the book with reference to the presumed needs of the members of the British Institute of Philosophical Studies. From this point of view it seemed to me both relevant and important to raise the question whether " Introductions" to Philosophy are in fact the best introduction to the subject. My preliminary remarks on that topic are suitable to the purpose of the Survey; they would have boen disproportionately long, but still not irrelevant in a regulation " review" of An Introduction to Philosophy.

To come now to Professor Brightman's special objections. I asserted that the book suffered from " a serious defect," viz. that it was written " in the belief that Philosophy has an important ' mission,' and that its value lies in finding a ' meaning ' for life, not solely in satisfying a desire to know." Professor Brightman replies that " the book neither contains nor implies" any such belief. I gather from his letter that he is in agreement with me that if the book did contain or imply such a belief it would suffer from a "serious defect." In reply, all that I can do is to quote some passages which certainly seem to me to assert and imply the belief in question :-

" From a different quarter, the religious camp, philosophy is also charged with being dangerous. Philosophy is said to be a foe to faith in life's highest and best. . . . The study of philosophy has often raised doubts and sometimes destroyed faith. No honest observer can deny that its study has occasionally caused spiritual disaster. . . Just as the good of studying the Bible probably predominates over the evil (although some Bible students come to distrust religion and perbaps even turn out murderers), so the good of philosophy predominates over the evil. It is tiue that some types of philosophy are openly opposed to any religious world view and that the exclusive study of such philosophies is dangerous to religion. But if religion be true, religion is more dangerous to those philosophies than those philosophies are to religion. Even so religion needs philosophy" (pp. 16-17). 


\section{JOURNAL OF PHILOSOPHICAL STUDIES}

"When the thinker has braved pitfall and gin, if he perseveres he will find that philosophy is capable of imparting a now moaning to life, of adding worth to every experience. Let us consider some of her higher functions " (p. 18 ).

"The unique contribution of philosophy to human life is that it furnishes a tool for the interpretation of the meaning and goal of life; a background, which gives unity to our science, our art, our literature, our morals, our religion, indeed to our whole civilization and also to our most intimate personal experiences" (p. 2I).

These quotations, which could be multiplied did space permit, seem to me to reveal a belief that the value of philosophy will be found in its finding a meaning for life; in this, he seems to assert, consists the " higher function" of philosophy. I maintain that Professor Brightman has implied that the value of philosophy lies in this "higher function"; I nowhere asserted that Professor Brightman had mado this value a test of $t r u t h$.

Yours truly,

Susan Stebbing. 